Magyar Honvédség Egészségügyi Központ

Központi Aneszteziológiai és Intenzív Terápiás Osztály

\title{
Az egészségüigyi ellátórendszerrel kapcsolatos lehetséges elvárások vegyi, illetve biológiai fegyverek alkalmazása esetén
}

\section{Dr. Péter Ádám orvos őrnagy}

Kulcsszavak: $A B V$-védelem, egészségügyi ellátás, rendszerfejlesztés, kémiai és biológiai fegyverek

Az első világháború befejeztével a tiltó nemzetközi egyezmények ellenére sem múlt el a vegyi és biológiai fegyverek alkalmazásának veszélye. A második világháborúban ugyan elmaradt az ilyen fegyverek alkalmazása, de a hidegháborúban mindkét hatalmi csoport továbbfejlesztette ezeket, még hatékonyabbá, még halálosabbá téve őket, időről-időre proxi háborúkban bevetve. A hidegháború véget értével Irakban, Iránban és Szíriában a reguláris hadsereg és a lázadó csapatok is használtak kémiai és biológiai fegyvereket. Az ilyen fegyverek megszerzésére terrorista csoportok is törekedtek. Ezen felül a nagyhatalmak célzott likvidálásokra is használták ezeket. Emiatt nem kizárható, hogy az egészségügyi ellátórendszerben Magyarországon is megjelenjenek vegyi vagy biológiai fegyverek áldozatai vagy sérültjei. Erre a lehetőségre az egészségügyi rendszert is fel kell készíteni.

"Sok ifjú van itt ma, akik a háborúban dicsöséget keresnek, de fiúk, ez itt maga a pokol. Elvihetitek ezt a figyelmeztetést a következö generációnak” [1] (William Tecumseh Sherman).

\section{Bevezetés}

A vegyi fegyverekről a legtöbbeknek a történelem órákon tanultak, az első világháború szörnyű állóháborúi, lövészárok harcai, gáztámadásai juthatnak eszébe. A vegyi fegyverektől sérült emberek szenvedése a mai Magyarországon élő emberektől térben messzinek, időben távolinak tünnek. A magyar egészségügyi ellátórendszerben ilyen sérültekkel évtizedek óta nem találkoztunk, így az ezirányú szakmai tudás marginalizálódott, jelentéktelennek tünik. Sajnos azonban a béke évtizedei ellenére sem elképzelhetetlen, hogy a vegyi vagy biológiai 
fegyverek okozta sérültekkel találkozzon az egészségügyi rendszer. A NATO tagság ugyan védelmet is jelent, de a belöle adódó külföldi katonai szerepvállalásunk kockázatot is jelent. A vegyi és biológiai fegyvereket tiltó egyezmények, az 1925-ben aláírt Genfi Protokoll [2], az 1993-ban aláírt CWC [3] és az 1972-es BWC [4] egyezmények ellenére ezek a fegyverek továbbra is, a modern korban is használatban vannak világszerte.

A környező háborúk, a terrorista aktivitás, és a közelmúltban lezajlott, vegyi fegyverekkel végrehajtott célzott likvidálások miatt szükséges a prehoszpitális ellátórendszer és a kórházi sürgős ellátással foglalkozó szakmák számára tanítani a vegyi és biológiai fegyverek áldozatai felismerésének lehetőségeit és a primer ellátás szakmai szabályait.

Milyen tapasztalatok vonhatóak le a történelemből ismert vegyi és biológiai támadásokból? Kerülhet-e a magyar egészségügyi ellátórendszerbe váratlanul vegyi vagy biológiai támadás sérültje? Fel van-e készülve a magyar egészségügyi ellátórendszer az ilyen sérültek ellátására? Milyen további lépések szükségesek az egészségügyi ellátás fejlesztése érdekében, a támadás sérültjeinek gyógyítására és a szekunder expozíciónak kitett egészségügyi személyzet védelmére?

\section{A vegyi és biológiai fegyverkezés történetéröl}

Ypern addigra elhagyatott városa körzetében a lövészárkaik mélyén megbúvó francia katonákat nem érhette váratlanul az 1915. április 22-én megindult újabb német tüzérségi támadás [5]. Az addigra már megszokott fülsiketítö ágyúlövések és lövedékbecsapódások mellett azonban Langemark falunál két, formálódó, sárgászöld felhőre lettek figyelmesek, ami az irányukba fúvó széllel gyorsan terjedt feléjük. A felhő a német 26 . hadtest speciális, vegyi hadviselésre kiképzett katonái által 4 kilométer széles arcvonalban kinyitott majd hatezer speciális, klórtartalmú gázpalackból származott. Ahogy a folyékony klórt tartalmazó gázpalackokat kinyitották, az azonnal elpárologva halálos felhőt formált. A megfelelő időjárás, a megcélzott francia katonák irányába fújó szél a gázfelhőt néhány perc alatt a francia katonák fölé vitte. A lövészárkokban megbúvó brit és francia katonák az árok mélyére bekúszó sürü gázfelhőben látni sem tudtak. Azonnal hevesen köhögni kezdtek, heves légúti váladékozás miatt a saját váladékukkal küszködtek, majd a levegőért küzdve eszméletlenül estek össze. A gázfelhőt a német gyalogság óvatos elörenyomulása követte. Ök a franciákkal ellentétben tudva a támadásról kezdetleges "gázmaszkkal”, légzőnyílásaik elé tett benedvesített pamutdarabbal haladtak elöre. Beköszöntött a vegyi fegyverek harctéri alkalmazásának kora [5].

A németek ötlete nem volt minden előzmény nélküli. Már az amerikai függetlenségi háborúban, 1862-ben javasolta egy civil geológus a konföderációs hadsereg vegyi anyagokkal, klórral, illetve hidrogéncianiddal töltött tüzérségi lövedékekkel történő támadását. A javaslata talán nem jutott el a megfelelő döntéshozókig, pedig az közvetlenül a Fehér háznak címezte, így a vegyi támadás akkor elmaradt [6].

Az Ypern mellett elkövetett első német kémiai támadás a francia egységekben iszonyatos pusztítást végzett. A német parancsnokot Falkenhayn-t arról tájékoztatták, hogy a szövetségesek 5000 katonát vesztettek, emellett több, mint 10000 katonát kellett sérüléseik miatt a harcmezőről kivonniuk [7]. 
A korábban hosszú állóháborúba torkolt, változó sikerű ütközetekhez képest hatalmas elörenyomulást értek el, 5 kilométer mélyen tudtak elöre haladni. Mai szemmel az ezért az öt kilométer elörehaladásért életét vesztett 5000 katona halála felfoghatatlan arányúnak tünik, de akkoriban az új harcmodor jelentős elörelépést jelentett. Használhatatlannak bizonyultak ugyanakkor a zsákmányolt hadieszközök. Amilyen fémtárgyat, fegyvert csak érintett a sürü klór gázfelhő, az oxidálódott, elszíneződött és rozsdássá vált. A sikert látva a német vezetés azonnal újabb gáztámadást vezényelt. Április 24 -én a hajnali órákban a kanadai egységeket érte heves ágyútüz és klórgáz támadás. A lövészárkokban ismét több ezer katona lelte halálát. Sokan azok közül is életüket vesztették, akiket átmenetileg a rögtönzött segélyhelyekre tudtak szállítani. A felcserek, orvosok nem tudták mivel állnak szemben, így rengetegen haltak meg a segélyhelyeken, így a háború elött kaszinóként müködő Le Touquet tábori kórházban is. Ypernnél az első támadástól számítva az első hónapban több, mint 500 tonna klórgázt vetettek be a németek [8]. Utólag tudható, hogy a németek a tervezett akciót nem tudták teljesen titokban tartani, egy elfogott német katona vallomásából tudták, hogy a német hadsereg gáztámadásra készül. A veszély mértékét azonban a szövetséges parancsnokságon nem ismerték fel, nem számoltak a várható súlyos veszteséggel, így a brit és a francia legfelsőbb parancsnokság nem rendelte el a visszavonulást vagy a gázpalackok bombázását [9].

Az Ypern-nél történtek, a vegyi fegyverek első harctéri alkalmazása, mint később látni fogjuk, több szempontból is figyelmezteti az utókort. A válogatás nélkül gyilkoló vegyi fegyverek a betiltásuk- ról szóló korai egyezmény, a Hágai Deklaráció ellenére továbbra sem kerültek a történelem szemétdombjára. Az 1915-ös támadás ellentmondott az addigra Németország által is aláírt Hágai Deklarációnak [10], aminek IV. 2 pontja tiltotta a fojtó, fullasztó hatású gázokat tartalmazó tüzérségi lövedékek használatát. A németek azonban arra hivatkoztak, hogy a Hágában 1899-ben aláírt egyezmény nem volt vonatkoztatható az Yperni támadásokra, mivel ott nem lövedékek révén, hanem gázpalackok kinyitása révén engedték ki a gázfelhőt. Cinikus érvelésüket sok mai, hasonló támadás elkövetője megirigyelhetné. A világháború háborús propagandája mellett is kitűnően provokatív és cinikus volt a Kölnische Zeitung híre, amelyben a támadásokat üdvözölték, azokat a nemzetközi joggal összeegyeztethetőnek és „különlegesen enyhe (harci) ametódusnak" neveztek [11]. Az első támadás tapasztalatai alapján ezután mindkét hadviselő oldal jelentős erőfeszítéseket tett újabbnál újabb, hatékonyabbnál hatékonyabb harcanyagok kifejlesztésére. A klórgáz után a foszgén, majd a kénmustár bevetése következett. A célba juttatás legmegfelelőbb módjainak kutatására, a saját harcoló alakulataik és civil lakosságuk védelmi eszközeinek kifejlesztésére mindkét harcoló fél komoly erőforrásokat biztosított. A háború és a fejlesztések elörehaladtával később aztán egyik félnek sem volt fenntartása a vegyi fegyvereknek az ellenség ellen történő alkalmazásával szemben, az aláírt tiltó egyezmények ellenére. A háborús gyártókapacitások nagy részét irányították át a vegyi fegyver gyártásra. Az angliai Porton Down, az amerikai Edgewood Arsenal, a francia Atelier de Pyrotechnie du Bouchet, vagy a német, országszerte elhelyezett Interessen Gemeinschaft mind a vegyi fegyverek tökéletesítésén dolgoztak. 
Az utólagos, hivatalos, szinte biztosan nem teljes összeírás szerint a háborúban összesen 180893 brit katona sérült meg vegyi fegyver támadásból, ebből később 6062 halt meg. Az Osztrák-Magyar Monarchia katonáiból 3000 esett el, 71300 sérült meg gáztámadásban [12]. Az ezekből az adatokból számolható 3\% alatti mortalitásra hivatkoztak a vegyi fegyverkezés támogatói, a módszert humánusnak nevezve, igyekezve elnyeri a parancsnokságok mellett a lakosság támogatását is.

A gáztámadásoknak a súlyos veszteségek, a sérültek nagy száma mellett volt egy fontos pszichológiai hatása is. A katonák harci morálját jelentősen csökkentette, a még harcmezők közelében ragadt lakosság is pánikban menekült. A vegyi fegyverekkel történő támadásnak napjainkban is legalább akkora pszichológiai hatása lenne, mint amekkora konkrét veszteséget tudna okozni [13].

\section{Vegyi fegyverek alkalmazása a XX. század háborúiban}

Bár a cikk elején említett átlagos olvasó valószínűleg a vegyi fegyverekkel az első világháborút kapcsolja össze, a vegyi hadviselés korántsem ért véget az első világháború befejeztével. A bolsevik lázadásban, feltételezések szerint a 1919-ben az afganisztáni harcokban, 1925-ben Marokkóban többször bevetették ezeket. Végül a 1925 június 17-én a világ 38 országának részvételével született meg a Genfi Protokoll (lásd fent), ami megtiltotta a „fullasztó, mérgező vagy más gázok, illetve hasonló folyadékok" és a biológiai fegyverek alkalmazását. Az egyezmény azonban nem tiltotta az ilyen anyagok előállítását, szállítását vagy tárolását, és nem tiltotta az egyezményt alá nem író országok ellen had- viselésben történő alkalmazásukat [14]. Így az egyezményt aláíró és ratifikáló országokban is folytatódott a vegyi fegyverek fejlesztése, legtöbbször védelmi célú kutatásnak álcázva, sőt az egyezményt többször nyíltan is megszegték, mint például a japánok az 1937-es kínai offenzívában vagy az olaszok 1936-ban Etiópiában [12].

A második világháború előestéjén, 1937-ben egy német vegyész, Schräder hatékonyabb rovarírtók után kutatva véletlenül, saját magán észlelte, hogy a rovarok ellen rendkívül hatékony anyagnak az emberi testre is hatása van. Önmagán látásvesztést, koncentrációzavart, pupillaszűkületet és légzési nehézségeket észlelt, amikor az anyaggal közvetlen kapcsolatba került. Felfedezte az első idegmérget, a tabunt [15]. A vegyület beszédes nevét a tabu szóból kapta. Az akkoriban már háborúra készülö Németországban felfedezése felkeltette a katonai tervezők figyelmét is. Felismerve az anyag hatásosságát külön gyárat építettek Elberfeld mellett az új harcanyag gyártásra és fejlesztésére. Az eredeti anyagot továbbfejlesztve készült el a tabunnál a még sokkalta mérgezőbb szarin 1938-ban, nevét a felfedezésében közreműködő német vegyészek nevének kezdőbetüiből formálva. A németek Lengyelország elfoglalása után a gyártókapacitásaikat növelték, a gyárakat a megtámadni tervezett Szovjetunióhoz közelebbi Dychernfurthba telepítették. A gyárban 1942-től a háború végéig tíz technikus és mérnök vesztette életét balesetekben. Ök voltak az első emberek, akik az újonnan felfedezett idegmérgek áldozataivá váltak [16]. A háború közepére a németek havi 12000 tonnányi harianyag előállítására voltak képesek, kifejlesztve vegyi aknákat, vegyi lövedékeket, vegyi gránátokat és vegyi bom- 
bákat egyaránt, sokszor a koncentrációs táborokba zárt embereken kísérletezve [17]. Hogy a náci Németország kegyetlen katonai vezetöi, illetve maga Hitler miért nem adott parancsot végül a vegyi fegyverek bevetésére a világháborúban nem egyértelmüen tisztázott. Több történész utal arra, hogy Hitler maga is megsérült az első világháborúban egy gáztámadásban, ezáltal gyülölte ezeket a fegyvereket. Nehéz elképzelni azonban, hogy a világháború végéhez közeledve egyre elkeserítőbb pozícióba kerülő Németország vezetöje Hitler, aki nem habozott a koncentrációs táborokba zárt milliókkal szemben vegyi anyagot alkalmazni, fenntartásai lettek volna azokat a harctéren alkalmazni a háború megfordítása érdekében. Még a háború kezdetén, Svájcban, 1939 szeptemberben a brit nagykövet átadott egy iratot a svájci külügyminisztériumnak, amelyet pár nappal később a német nagykövet is aláírt. Ebben vállalták, hogy országuk tartózkodni fog a vegyi fegyverek bevetésétől, kötelezőnek ismerik el magukra a Genfi Protokollt. A hitleri Németország azonban több hasonló egyezményt is felmondott vagy megszegett a világháború alatt, így önmagában ez sem lehetett a náci vegyi fegyverek bevetése elmaradásának az oka. Hitler többszöri fenyegetőzése, utalásai ellenére, katonai parancsnokai sürgetése ellenére azonban a vegyi fegyverek bevetésére végül nem adott parancsot. Hitler talán inkább a megtorlástól tarthatott. Emellett Speer és Ambros tábornokok is igyekeztek lebeszélni a fegyver alkalmazásáról [18]. A németek feltételezései ellenére a szövetségesek nem voltak az idegmérgek titkának tudtában, egészen 1945 áprilisáig, amikor egy német fegyverraktárat elfoglalva ismerték fel a németek fejlesztéseinek rémisztő súlyát. A második világháború szörnyü- ségeihez, hatalmas katonai és civil veszteségeihez egy esetleges vegyi fegyverekkel vívott háború újabb tízezrek halálát és akár százezrek sérülését okozta volna.

A németek mellett az angolok is tartózkodtak a vegyi fegyverek bevetésétől. Amikor a náci Németország V-1 támadásai megindultak, az angol hírszerzés úgy tudta, hogy a fegyver modernebb, V-2 változata már sokkal pusztítóbb robbanófejjel lesz felszerelve. A védekezés lehetőségeit taglalva Churchillben felmerült a vegyi fegyverek bevetésének lehetősége. Az angol hadsereg vezetése mellett a Joint Planning Staff is feladatul kapta, hogy ennek lehetöségeit és következményeit megvizsgálja. A brit Joint Planning Staff [19] hosszú napok után egy hosszú jelentést állított össze, amelyben az amerikai és brit erők bombázóegységeinek bevetését, kénmustár alkalmazását majd gyújtóbombák ledobását javasolták taktikai célpontok mellett 4060 nagyvárosra is. Számításuk szerint ez a támadás megtörte volna a németek morálját. Viszont a katonai tervezők azt is kijelentették, hogy bár az első vegyi támadás meglepetésszerű alkalmazása taktikai előnyt jelenthetett volna, a Genfi Protokoll megszegése mellett a Normandiában partraszállt szövetséges csapatok előrenyomulását is hátráltatta volna, és a civil lakosságot is szembeállította volna a szövetséges haderőkkel. Számítottak arra is, hogy a németek azonnal megtorolták volna a támadást, akár London ellen intézett vegyi támadással, ami a rengeteg halott és sérült áldozat mellett a hátország civil morálját is szétbombázta volna. Összességében a Joint Planning Staff a vegyi fegyverek bevetése ellen foglalt állást [20]. Churchill, bár kijelentette, hogy nem ért egyet a végkövetkeztetéssel, elfogadta a tervezők döntését és a vegyi fegyverek beve- 
tését „a rosszabb időkre” halasztotta amelyek a háború elörehaladtával nem következtek be. A szövetségesek sikeres elörenyomulása Európában nem tette szükségessé a vegyi fegyverek bevetését.

Az amerikai katonai parancsnokságokon is felmerült a vegyi harcianyagok bevetése, föleg a Csendes óceáni hadszíntéren, Iwo Jima körzetében. A Lethbridge Report vegyi fegyverek bevetését javasolta. Az ajánlás a legfelsőbb katonai parancsnokok támogatását is bírta, de Roosevelt elnök megakadályozta a vegyi fegyverek bevetését.

A lengyel ellenállók viszont felhasználták mikrobiológiai tudásukat. Egyfajta hamis biológiai fegyvert vetettek be. A Rozwadów városában dolgozó orvosok meghamisították pácienseik dokumentációit és laborleleteit úgy, hogy azok tífuszt igazoljanak. A német harcoló alakulatok a konfirmáltnak vélt tífuszos gócpontot elkerülték, így Roswadów városában 8000 civil menekült meg [21].

A második világháborúban tehát épp hogy csak, de a reguláris harcoló felek elkerülték a vegyi fegyverek alkalmazását. Ez azonban nem jelentette azt, hogy pusztító erejével ne lettek volna tisztában, és hogy a háború után ne fejlesztették volna tovább a nem konvencionális fegyvereiket. Ebbe a fegyverkezési versenybe a Szovjetunió is belevetette magát. Ráadásul mindegyik, a németek ellen harcoló ország igyekezett a német vegyi fegyverek titkát, az ezeket gyártó gyárakat megszerezni, és magának megtartani - a viszszavonuló németek pedig az elraktározott idegméreg készleteket megsemmisíteni, a dokumentumokat elégetni. A háború végére azonban minden harcoló fél megismerte az idegmérgek titkát és saját céljaira igyekezett továbbfejleszteni azt.

A háború végén Amerika bevetette a atombombáit Japánban. A Szovjetunió akkoriban még nem bírt hasonló nukleáris képességgel, így alternatívaként a vegyi, és még inkább a biológiai fegyverkezés felé fordult.

\section{Biológiai fegyverkezés a XX. században}

A biológiai fegyverkezésben a Szovjetunió a távol-keleti hadszíntéren elfogott japán hadifoglyok beszámolóira is támaszkodhatott. A moszkvai rádió nyilvánosan jelentette be a negyvenes évek végén, hogy japán hadifoglyokat biológiai hadviseléssel vádolnak meg. Bár a tárgyalás a kornak megfelelően megrendezett volt, a japánok beszámolói hitelesnek tünnek. Eszerint a japán hadsereg a világháborúban elfogott kínai katonákon kísérletezett, többek között gáz gangréna és anthrax bombákkal fertőztek meg hadifoglyokat, a néhány napon bekövetkező halálukat pedig gondosan dokumentálták [22]. A szovjetek különösen erős érdeklödésének az is oka volt, hogy saját, meglevő kapacitásukat fejlesszék a japánoktól megtudottak révén. A Szovjetunió ugyanis már 1930-tól kísérletezett biológiai fegyverekkel az Aral-tó szigetén létrehozott titkos létesítményeikben, a pestist, anthraxot, takonykórt (glanders) arany háromszögnek nevezve, de a tularémiát, leprát, kolerát, tetanuszt és tífuszt is vizsgálva. A korábban szövetséges hatalmak a háború után ellenségekké váltak, egymás elleni háborúra készültek. Az amerikai és brit hírszerzésnek igen kevés információja volt a szovjet biológiai fegyverprogram kiterjedtségéről. A szovjetek teljes titkolózásba burkolództak. Ugyanakkor tudható volt, hogy a biológiai program létezik. Még 1938-ban ismerte el egy New York Times-ban megjelent interjúban egy szovjet tábornok, hogy bár tartják ma- 
gukat a Geneva Protokollhoz, de teljesen felkészültek visszavágni az agresszoroknak, ha azok nem konvencionális fegyverekkel intéznek ellenük támadást [23]. A szovjetek bár létesítményeiket igen szigorúan őrizték, a munkabiztonságra kevesebb figyelem jutott. Nem egyszer történt olyan baleset, amikor a fertöző anyag kiszabadulva ártatlanokat fertőzött meg. A legsúlyosabb, több száz ember halálát okozó eset 1979-ben történt.

Szverdlovszk, a mai Jekatyerinburg szigorúan őrzött 19-es szovjet katonai létesítményében antraxspórákból készítettek igen finom port, amit aeroszolként terveztek használni biológiai fegyverekben. Katonai alkalmazás esetén a finom por a levegőben robbanva messzi területeket fertőzött volna meg. Szürőegységeket alkalmaztak, hogy az anyag a környezetbe ne juthasson. 1979. március 30-án azonban az egyik ilyen szürő eltömődött. Egy technikus ezt észlelte és az előírások szerint leállt gyártás mellett a szüroot eltávolította. A csereegységet, az új szürőt viszont nem szerelte vissza azonnal, hanem feljegyzést hagyott hátra, hogy a szürő cseréje szükséges. A gyárba érkező új váltás, az új müszak felügyelője erről nem tudva a gyártósort újraindította, ezzel nagy mennyiségü anthrax spóra került a gyárból a levegőbe, lassan lebegve a város felett, majd a szél irányának megfelelően 50 kilométeres távolságra is eljutott. Néhány nap múlva jelentkeztek az első megbetegedések. Néhány héten belül több, mint száz ember halt meg. A szovjet hatóságok fertőzött hús fogyasztásának próbálták meg beállítani a történteket. A KGB a kórházi dokumentációt, a halálozási számokat is meghamisította. Egy, a harvardi egyetemen dolgozó professzort, Matthew Meselson-t is beengedték, aki az elé tárt adatok alapján megerősítette, hogy étel- mérgezés történhetett. Évekkel később azonban kénytelenek voltak elismerni a szovjet vezetők a nyilvánvalót. A gyárból kiszabaduló felhő a szél irányának megfelelően terjedve, az abban a pillanatban ott dolgozókat betegítette meg. A holttestekből évtizedekkel később is sikerült a rendkívül ellenálló anthrax spórákat azonosítani, megerősítve, hogy súlyos, katonai eredetű anthrax fertőzés történt. A túlélőkkel, helyi lakosokkal beszélgetve Meselson professzor is megváltoztatta a véleményét[24] és a Science-ben megjelent írásában nemcsak az anthrax fertőzés tényéről számolt be, hanem később arról is, hogy a helyiek elmondása szerint több, mint 60 hasonló baleset történt csak ebben a komplexben. A szovjet biológiai fegyverprogramot ez akkoriban természetesen nem vetette különösképpen vissza. Az országszerte működő, Biopreparat néven hálózatba szervezett katonai biológiai laborokban tovább kísérleteztek kórokozókkal és igyekeztek a célba juttatásukhoz is legmegfelelőbb eszközöket kifejleszteni. A Biopreparat vezetöje, Kanatzhan Alibekov később az Amerikai Egyesült Államokba diszszidált, ahol részletesen beszámolt a kiterjedt szovjet biofegyver programról. Biohazard című könyve a széles közönség számára is elérhető. A szverloszki gyárba azóta sem engednek látogatókat. A gyár azóta is folytatja müködését, részben földalatti üzemekben [25]. Az 1990-es években az orosz gazdaság hanyatlásával sok tudós, technikus, kutató, mikrobiológus vesztette el az állását a szovjet Biopreparat egységeiben. Sokan kaptak ugyan az Amerikai Egyesült Államoktól támogatást, és a oroszok is igyekeztek némelyik egységüket békés célokra, vakcina termelésre, antibiotikum készítésre átállítani. A munkájukat elvesztő tudósok, mikrobiológusok nagy 
tömege külföldön kapott új megélhetést, a biotechnológiai tudásukat Kubának, Észak-Koreának, Iránnak, Iraknak, Szíriának adva át [25].

A hidegháborúban a vegyi és biológiai anyagokat nemcsak az ellenséges katonák pusztítására tervezték használni. A közvetlen halálozás mellett legalább olyan fontos cél volt a harcképtelenné tétel, az egészségügyi ellátórendszer túlterhelése, megbénítása. Emellett számtalan olyan anyagot kísérleteztek ki, amelyek az ellenséges, de akár a saját katonák viselkedését módosította, harcképtelenné vagy éppen ellenkezőleg, „szuperemberré” téve őket. A pszichotróp hatású meszkalinnal, LSDvel, annak továbbfejlesztett, technikailag is könnyebben bevethető változatával, a BZ-vel, amfetaminnal folytak kísérletek. Az amerikai Chemical Corps célja a kísértetiesen, cinikusan hangzó "halottak nélküli háború" elérése volt. A vegyi anyagokkal a hagyományos fegyverekkel harcoló alakulatok taktikai hátrányát is igyekeztek csökkenteni. A vietnámi háborúban az esőerdőt írtandó többezer tonna dioxin szennyezést, a tároló hordó színe alapján Agent Orange-nak is hívott anyagot diszpergáltak alacsonyan szálló repülökről. Az anyagot az emberekre teljesen ártatlannak mondták, a növényzetet viszont extrém módon stimulálva az esőerdő kipusztulását okozta. Később kiderült, hogy a vietnámi harcosok, de az USA katonák között is extrémen megemelkedett a rákos megbetegedések aránya, utódjaik között pedig a születési rendellenességek elöfordulása - emberre tehát az anyag ugyanúgy káros volt, mint az eredeti célra, a növényzetre.

A hidegháború végére minden nagyhatalom hatalmas készleteket halmozott fel kénmustárral, foszgénnel, idegmérgekkel töltött rakétákból. A befolyásolási övezetekben, a vélt ellenséghez lehető legközelebb is tároltak nagy mennyiségben mérgező harcanyagokat, az USA Nyugat-Németországban és Okinawán, Japánban, a Szovjetúnió NDK-ban. Biológiai hadviselésben talán a szovjetek jártak legelőbb, óriási mennyiségben tároltak biológiai fegyvereket. Antrhaxszal, tularémiával, pestissel, kolerával, tífusszal, ricinnel töltötték ezeket, de igyekeztek az újonnan előbukkanó vérzéses lázakat is katonai célra alkalmassá tenni. Emellett génmódosításokkal az amúgy is letális baktériumokat az ismert antibiotikumokra rezisztenssé tették. Talán a legfejlettebb és legrémisztőbb módszer a chimera vírusok kifejlesztése volt, amikor is a vírusok tulajdonságait géntechnológiai módszerekkel úgy módosították, hogy a lehető leghalálosabb, legellenállóbb és legfertőzőbb legyenek.

A változatos kémiai és biológiai fegyverek tehát a hidegháború végére rendelkezésre álltak. Rendelkezésre állt a mögöttes tudás, a technológiai részletek, az alkalmazás leghatékonyabb módjának ismerete. Ekkora viszont már nemcsak a nagyhatalmak voltak ezen tudás birtokában, hanem a kisebb államok is. Önerőből, vagy átállt tudósok segítségével számtalan állam fejlesztette saját kémiai és biológiai fegyver programját.

\section{A közel-keleti országok vegyi és biológiai fegyverprogramja}

Irán a muszlim többségü volt szovjet tagköztársaságokkal - Örményországgal, Kazahsztánnal - szorosra füzte kapcsolatait azok önállósodása után. A Biopreparátnak sok üzeme volt ezekben a tagköztársaságokban. Ebből egy teljes, müködő örményországi üzemet adtak el az örmények Iránnak [25].

Iraknak is volt biológiai fegyverprogramja. Egy a New York Timesban 
2002-ben megjelent cikk szerint, amely CIA forrásokra támaszkodott, meg is nevezték azt az orosz tudóst, dr. Nelli Maltseva-t, aki 1990-es látogatása során Irakba vitte a korábban szovjetek által katonai célokra fejlesztett himlő vírust, emellett a üzemeltetési, technológiai adatokat is átadott [26]. Irak ráadásul korábban sem csinált titkot abból, hogy birtokában van vegyi fegyvereknek és azokat kész bevetni is. Irak katonai vezetői "rovarírtók” használatával fenyegették meg a „betolakodó rovarokat”, utalva a birtokukban lévő vegyi fegyverek hatásmechanizmusára is. Irak végül be is vetette a vegyi fegyvereit az 1980-as évek háborúiban, idegmérgeket és kénmustárt alkalmazva a kurdok és az iráni csapatok ellen. A Faw félszigeten támadó Iráni egységek a vegyi támadásokban az első világháború vegyi csapásaihoz mérhető vegyi támadásokat szenvedtek, legalább 150000 iráni katona halálát okozva ezzel. Az iraki hadsereg később a civilek ellen is bevetette vegyi fegyvereit - volt, hogy ezekkel direkt a helyi kórházakat célozta [27].

Szíria 2013-ban vegyi fegyvert, szarint vetett be a lázadók ellen Aleppo-nál, Ghouta és Saraqib térségében. A nemzetközi felháborodás hatására 2014ben a vegyi fegyvereket a szíriai katonaság ugyan állítólag megsemmisítette, 2016-ban újra klórgáztámadást hajtottak végre Talmenes-nél. 2016 decemberében pedig ismét szarinnal támadták az ISIS Uqairabat-közeli állásait. Az ENSZ és az amerikai hadsereg vizsgálatai a vegyifegyver támadásokat megerősítették és azokat egyértelmüen az Assad vezette szíriai kormány, a szíriai hadsereg számlájára írták. Nyilvános adatbázisokban [28] és sokszor a háborúról tudósító médiában ezeken a megerősített támadásokon kívül is számtalan, meg nem erősített, fel- tételezett vegyi fegyver támadás szerepelt. A Human Rights Watch szervezet 2018 áprilisi jelentése szerint összesen 85 esetben tudták megerősíteni a vegyi fegyver használatát a polgárháborúban [29].

\section{Terrorszervezetek vegyi és biológiai fegyverkezése}

A vegyi és biológiai fegyvereket nemcsak a nagyhatalmak, állami szereplők használták céljaik elérésére. Ismert, hogy az al-Kaida terrorhálózat nukleáris fegyverek beszerzésére törekedett, de bőséges financiális hátterük ellenére sem sikerült a jól őrzött állami raktárakból ilyenre szert tennie. Ugyanakkor az USA-ban 2002-ben több év börtönre ítélték $J o$ sé Padilla-t, aki az Al-Qaeda hálózattal kapcsolatban állva, tőlük kiképzést kapva "piszkos bomba", sugárzó anyagot tartalmazó bomba robbantására készült. 2004-ben ausztráliai nukleáris intézményekben gyanúsan viselkedő dolgozókat tartóztattak le, akik szintén piszkos bomba készítését tervezték.

$\mathrm{Az}$ ISIS terrorszervezet a szíriai polgárháborúban kénmustár klórt és szarint vetette be a városi harcok során. A japán Aum Shinrikyo szekta teljesen civil környezetben támadott szarinnal. A szekta 1994-ben Matsumoto városában 8 embert ölt meg szarin támadással. A helyi egészségügyi hatóságoknak több, mint 500 embert kellett ellátni különböző súlyosságú tünetekkel. Korábban sikertelenül próbálkoztak anthrax támadással, de később sikerült szarint és VX idegmérget szintetizálniuk. A matsumotoi támadással a helyi, korábban a szekta ellen ítélő bírókat célozták, de céljuk volt a szarin hatásosságának kipróbálása is. $12 \mathrm{~kg}$ folyékony szarint bocsátottak ki egy átalakított teherautó rakteréből, ami a környező épületekbe, az éjszakára nyitva hagyott 
ablakokon, szellőzőnyílásokon bejutva mérgezett [30]. Ezt a terrorcselekményt egy névtelen tipp ellenére a helyi hatóságok nem tudták összefüggésbe hozni a világvége közeledtét hirdető szektával. 1995-ben újabb támadás történt, ez alkalommal a tokiói metróban. 1995 március 20-án szarint engedtek szabadon a tokiói metró szerelvényeiben. 13 halott, 54 súlyos sérült és több mint 1000, könynyebben sérült lett a támadás eredménye. A civil környezetben végrehajtott támadásnak számos, az ABV védekezésben máig irányadó tanulsága volt. Ismert, hogy a támadás után elsőként helyszínre érkező mentőegységek - érthető módon - nem voltak felkészülve szarin támadásra, nem viseltek megfelelő védőeszközöket, így számtalan sérült az egészségügyi személyzetből került ki. A kórházakat, a sérülteket ellátó személyzetet azonban akkor sem értesítették, amikor a hatóságok számára egyértelművé vált, hogy szarin támadás történt. Ezáltal sok, a kórházi ellátásban résztvevő személy is sérültté vált a szekunder expozíció miatt. Ez felhívja a figyelmünket arra, hogy tömeges sérülések esetén elengedhetetlen egy közös irányító szervezet felállítása, a felszámolásban résztvevő szervezetek döntéshozóiból az információk megosztása érdekében. A tokiói támadásban számtalan sérült a mentőszervezetet megkerülve a legközelebbi kórházakat kereste fel. Számolnunk kell tehát azzal, hogy hasonló helyzetben nemcsak azok a kórházak lesznek érintettek, ahová a felkészülést koncentráljuk, hanem ahova a betegeket irányítani tervezzük. A rengeteg sérült, meghaladva a mentőszolgálat szállítókapacitását saját lábán fogja felkeresni az általa ismert legközelebbi ellátóhelyet. Emiatt, ahogy a későbbiekben erről szó lesz, nem elegendő néhány egészségügyi szolgáltatót kijelölni az ellátásukra. A vegyi fegyverek áldozata- inak ellátásához szükséges tudást terjeszteni kell a teljes sürgősségi ellátórendszerben. A támadások utóéletéről beszámoló irodalomban olvasható, hogy hatalmas számban keresték fel az egészségügyi szolgáltatókat olyan betegek, akik a hírekben hallottak a támadásról és magukon a tüneteket felfedezni vélték - később kiderült, hogy nem sérültek. Az úgynevezett „worried well” populáció további terheket ró az ellátórendszerre, így a valóban sérülteken felül sok fizikálisan tünetmentes, de pszichés tüneteket mutató "érintettek" ellátására is fel kell készülni [31].

A vegyi és biológiai fegyvereket többször alkalmazták célzott likvidálásokra is. Georgi Markov bolgár disszidens írót átalakított esernyőből kilőtt apró, ricint tartalmazó lövedékkel végezték ki 1978ban Londonban. Egy másik bolgár diszszidens, Vladimir Kostov pedig csak a fegyver hibájából adódóan élt túl egy hasonló támadást Párizsban [32].2018-ban pedig továbbfejlesztett, „negyedik generációs” idegmérget használtak Sergei Skripal ellen. Ö és lánya ugyan túlélte a támadást, de a vegyianyagot tartalmazó fiolát megtaláló pár női tagja belehalt a mérgezésbe [33]. Az újabb, negyedik generációs idegmérgek újabb alkalmazásának veszélyére is tekintettel több amerikai minisztérium közös ajánlást adott ki az ilyen fegyverek áldozatául esett emberek egészségügyi ellátására [34].

\section{A hazai egészségügyi rendszer lehetőségei és felkészültsége vegyi és a biológiai fegyverek alkalmazása esetén}

A vegyi és biológiai fegyverek hatalmas fejlődésen menve keresztül továbbra is használatosak harcérintkezésekben, katonák és civilek százainak halálát okozva, de terrorcselekményekben és célzott 
likvidálásokban is, a modern kor ezeket tiltó egyezményei ellenére is. Nem kizárható tehát, hogy a jövőben az ilyen fegyverek hatásának áldozatául esett emberek Magyarországon is megjelenjenek. Akár a környezetünkben vívott háborúk, akár behurcolt megbetegedések, akár az államunk területén végrehajtott terrorcselekmény vagy targeted killing következtében. Emiatt a vegyi és biológiai fegyverek elleni megfelelő védekezés érdekében nemcsak a Magyar Honvédség vegyivédelmi eröit szükséges felszerelni megfelelő információkkal, képességekkel és tudással. A magyar hírszerző szervezeteknek a katonai és civil környezetben is számolnia kell ilyen támadások bekövetkeztével, még a mai, békés környezetben, Magyarországon is. A védekezésben mindig komoly szerep hárult és fog hárulni a hírszerzésre, a kockázatelemzésre, amely a beérkező információk elemzésével a védekezésben résztvevő nem katonai szervezeteket is előzetesen értesíteni tudja a várható támadásról. Ugyanakkor a civil környezetben bekövetkező vegyi és biológiai támadások, terrorcselekmények kezelése érdekében nemcsak a fegyveres szervezeteket és a katasztrófa elhárítást, de az egészségügyi ellátórendszert is képessé kell tenni a vegyi vagy biológiai támadások sérültjeinek felismerésére, a szükséges konfirmáló vizsgálatok elvégzésére, a megfelelő szakmai ellátásra és az ellátók személyes védelmére - mivel az első világháborúban megkezdett vegyi és biológiai hadviselés napjainkig sem ért véget. A vegyi és biológiai fegyverek, illetve vegyianyagok hatásait, az ellátás módjait nemcsak az első világháború felcsereinek és orvosainak, de a mai, magyar sürgősségi ellátásban, primer betegellátásban dolgozó orvosoknak, mentőtiszteknek is tanítani, ismerni kell.

Magyarországon az egyetemi orvosképzésben, majd a posztgraduális sür- gősségi szakorvosi vagy aneszteziológiai szakorvosi képzésben a vegyi és biológiai fegyverekről nem esik érdemben szó, annak ellenére, hogy ezen szakmában dolgozó orvosok azok, akik a szakmájukból adódóan elsőként találkozhatnak ilyen sérültekkel. Az ilyen képzés hiánya nemcsak a sérültek megfelelő ellátását hátráltatja, hanem a fegyverek sajátságaiból adódóan az ellátószemélyzetet is veszélyezteti.

A fegyverfejlesztés elmúlt száz éve alatt sokféle hatásmechanizmusú és szerteágazó kémiai jellemzőkkel bíró anyagokat fejlesztettek ki. Az angliai Public Health England szerkesztette 2018-as kiadványt [35] a civil egészségügyi személyzetet célozva adták ki, összefoglalva legfontosabb tudnivalókat a vegyi, biológiai, radiológiai és nukleáris fegyverek sérültjeinek ellátásával kapcsolatban. A legfontosabb, elsőként kiemelt ajánlás a következő: ha három vagy annál több, ismeretlen okból eszméletlen sérülttel találkozik az ellátó, feltételezhető a vegyianyagok hatása, így csak megfelelő védőeszközök birtokában lehet megközelíteni a helyszínt. A hazai gyakorlatban persze előfordul három vagy annál több sérült a fütési időszakban szénmonoxid mérgezés kapcsán is. Ennek észlelésére azonban a mentöszolgálat egységei és a katasztrófavédelem egységei is rendelkeznek megbízható műszerrel. Az angol kiadvány ajánlása tehát hazai környezetre úgy alkalmazható, hogy ha 3 vagy annál több, ismeretlen okból eszméletlen sérülttel találkozik az ellátó és a szénmonoxid érzékelő nem jelez, fel kell tételezni, hogy eszméletlenségüket CBRN (Chemical, Biological, Radiological, Nuclear) incidens, vegyi vagy biológiai harcanyag okozhatja. Az angliai ellátórendszerben ilyenkor speciális képzettségü és felszereltségü egységek riaszthatók. Ezek a hazai gyakorlatban nem állnak egyelöre rendelkezésre. Az 
angliai kiadvány részletes útmutatást tartalmaz a megfelelő védőruházat, védőfelszerelés kiválasztására és felvételére is, a látható klinikai jelek alapján értékelve a sérültek állapotát és sérülésük feltételezhető okát. A hazai gyakorlatban helyszíni vagy kórházi sürgősségi egészségügyi ellátószemélyzet nincs megfelelően felkészítve a vegyi vagy súlyosan fertőző biológiai fegyverek esetén alkalmazandó ruházat viselésére.

Az ellátásban a betegek észlelése után a következő kérdés a mentesítés biztosítása. A külföldi tapasztalatok alapján is ez az egyik legnehezebben megoldható feladat. Az ilyen, tömegpusztító fegyverek bevetése esetén sokszor tömeges sérültellátási helyzettel találkozhatunk. Ilyen esetben a megfelelő áteresztő képességü mentesító állomás felállítása, üzemeltetése, a megfelelő személyzet és annak időnkénti rendszer cseréjének biztosítása, a mentesítésig szükséges crowd-control megoldása hatalmas feladatot jelentenek minden ellátórendszer számára. A tervezés folyamán ráadásul figyelembe kell venni az prehoszpitális ellátást kikerülő, közvetlenül kórházakba áramló sérülteket is, akiknek mentesítését a kórházakon belül kellene megoldani. Külföldi tervezőkkel beszélve erre még nyugati országokban sincs teljesen kidolgozott terv. A feladat nagysága, változatossága miatt ad hoc megoldások lehetnek szükségesek. Ilyen megoldások viszont csak akkor lehetnek hatásosak, ha azokat megfelelő tudással felvértezett, vegyi mentesítésben jártas, a várható egészségkárosodás klinikai tüneteit ismerő és a tömegirányításban tapasztalatokkal bíró szervezetek kijelölt vezetői közösen hozzák meg. Külön nehézséget jelent biológiai támadások esetén, hogy ezek tünetei a támadás időpontjához képest csak napokkal később jelentkeznek és a tünetek eleinte aspecifikusak, felsőlégúti vírusinfekcióra emlékeztetőek. Láz, köhögés, orrfolyás jelentkezik, amikkel a betegek jellemzöen háziorvosukhoz fordulnak. A fertőzés után jóval később kialakuló, a kórokozó konkrét patomechanizmusára jellemző eltérésekkel (hólyagok, vérzéses köhögés, stb.) szintén az alapellátó rendszerbe kerülnek a betegek elöször. Így, míg a vegyi fegyverekkel kapcsolatos képzést elsősorban a sürgősségi orvosok, aneszteziológusok részére szükséges szervezni, a biológiai fegyverek hatásának felismerését az alapellátók, a háziorvosok részére is szükséges oktatni. A hírszerzésnek azonban mind a két esetben alapvető szerepe van. Amennyiben a felderített információk alapján ilyen fegyverekkel történő támadás valószínüsíthető, arról az operatív szempontok figyelembevétele mellett tájékoztatni kell az egészségügyi ellátórendszer szereplöit, hogy a sérültek felismerése időben megtörténhessen és ezáltal az ellátásuk késlekedést ne szenvedjen.

Külön figyelmet kell fordítani a vegyi, biológiai támadások menedzselése kapcsán a megfelelö, törvényszéki és laboratóriumi szempontoknak megfelelő mintavételre. Magyarországon az elmúlt évtizedekben a honvédségen belül létrehozásra került az a képesség, amely a biológiai anyagokat, kémiai anyagokat identifikálni tudja. A képesség kihasználásához, az eredményes értékeléshez azonban a megfelelő mintavételt és a vizsgálatok elvégzésének szervezési feladatrendszerét is biztosítani kell.

\section{A magyarországi egészségügyi ellátórendszer fejlesztési irányai}

Magyarország a NATO tagság kapcsán a szövetség védőernyője alá került.

A szerződés harmadik cikkelye [36] nemcsak a kollektív védelemről szól. 
A cikk szó szerinti idézete „A jelen szerződésben kitűzött célok hathatósabb elérése érdekében a Felek külön-külön és együttesen, folyamatos és hathatós önsegély és kölcsönös segítség útján, fenntartják és kifejlesztik egyéni és kollektív védelmi képességüket fegyveres támadással szemben" alapján minden országnak önállóan, folyamatosan fejlesztenie kell a saját képességeit is. Ide sorolható a vegyi, biológiai, radiológiai és nukleáris fegyverekkel szembeni katonai és civil egészségügyi védekezés is. A kollektív védelem sem csak az adott esetben szükségessé váló, konkrét harci tevékenységben nyilvánul meg, hanem a tagállamok közötti hatékony kommunikáció, a tapasztalatok, a képességek megosztásában, közös gyakorlatokban is. A tagság révén Magyarország hozzáférhet a NATO standardjaihoz. A 2018ban kiadott AMedP-7.1 NATO Standard a CBRN sérültek egészségügyi ellátásáról szóló részletes dokumentum [37]. Nem szükséges tehát új, teljesen önálló hazai irányelveknek az alapoktól kezdett részletes kidolgozása, kifejlesztése, de szükségesnek látszik a vonatkozó NATO irányelvek alkalmazása az egészségügyi rendszer felkészítése, az oktatás és az ellátásszervezés vonatkozásában. Megemlítendő, hogy a NATO AMedP-7.2 CBRN First Aid Handbook-ban [38] szintén az ellátás elsődleges szempontjaira koncentrálva megtalálhatók a vegyi, biológiai vagy radiológiai-nukleáris fegyverek sérültellátási szempontjai.

\section{Az egészségügyben megfogalmazható fejlesztési irányok}

A történelmi tapasztalatok, a hazánkban sem kizárható $A B V$ támadások és a vonatkozó NATO irányelvek, alapelvek alapján tehát a magyar egészségügyi ellátórendszer számára a szerző véleménye szerint következő fejlesztési javaslatok tehetők:

- A Magyar Honvédség Egészségügyi Központ (MH EK) vezetésével a vegyi, biológiai, radiológiai és nukleáris fegyverek hatásaival és különösen azok egészségügyi ellátási módjaival foglalkozó dedikált egészségügy fejlesztése.

- A társszervekkel (Terrorelhárító központ, Katasztrófavédelem, Országos Mentőszolgálat), a Honvédség vegyvédelmi csapatainak képviselőivel MH GAVIK (MH Görgei Artúr Vegyivédelmi Információs Központ), és a fenti MH EK egészségügyi személyzettel egy közös egyeztető bizottság létrehozása a jelenleg rendelkezésre álló eszközök és kapacitások értékelésére, a szükséges tárgyi és személyzeti fejlesztésekkel kapcsolatos javaslatok kidolgozására.

- A jelenlegi prehospitális és kórházi mentesítési kapacitások, a rendelkezésre álló konfirmáló laborvizsgálatok felülvizsgálata, szükségszerü bővítése.

- A tapasztalatok birtokában a hazai sürgősségi ellátórendszer és alapellátás szereplői számára egy egynapos, akkreditált tanfolyam szervezése.

- Az EBP keretében kidolgozásra kerülő új kórházi kapacitások tekintetében javaslattétel a kémiai, biológiai, radiológiai és nukleáris támadásokra vonatkozó szempontok figyelembevételére, a megfelelő mentesítési lehetőségek, elkülönítési lehetőségek megteremtésére.

\section{Összefoglalás}

A fenti, a magyar egészségügy vegyi, biológiai, radiológiai és nukleáris fegyverek sérültjeinek ellátásával kapcsolatos tuda- 
tosság javításáról, az ország ilyen irányú védelmi képességének javításáról szóló javaslatok megvalósítása érdekében a hazai civil és katonai egészségügy felkészítése, a társszakmák együttmüködése és megfelelő elhivatottság és előrelátás szükséges. $\mathrm{Az}$ ellátáshoz szükséges felkészültségre, szervezettségre, tudásra - ugyan mindannyian reméljük, hogy Magyarországon sohasem lesz szükség, de amennyiben ilyen támadás mégis bekövetkezne - csak elözetes tervezéssel, oktatással, a személyi védelmi, a szükséges laboratóriumi és egészségügyi eszközrendszer biztosításával képzelhető el a sérültek ellátása, megmentése és az ellátó személyzet megóvása.

\section{Irodalom}

[1] Sherman, W.T.: https://citatum.hu/szerzo/ William_Tecumseh_Sherman

[2] Genfi Protokoll (Geneva Protocol) 1925-ben kidolgozott nemzetközi egyezmény, amely a kémiai és biológiai fegyverek harctéri alkalmazását tiltja, de nem tiltja azok fejlesztését és előállítását

[3] CWC: Chemical Weapons Convention. 1992ben kidolgozott nemzetközi egyezmény a kémiai fegyverek használatának, fejlesztésének, előállításának, raktározásának és átadásának betiltására.

[4] BWC: Biological Weapons convention 1972-ben kidolgozott egyezmény a biológiai és toxin alapú fegyverek alkalmazásának tiltásáról

[5] The release of poison gas 100 years ago changed the face of World War I and gave humanity a new weapon of mass destruction. https://chemicalweapons.cenmag.org/whenchemicals-became-weapons-of-war/ DOI: $10.2307 / 2708558$

[6] Wyndham, M.: The Idea of Chemical Warfare in Modern Times. Journal of the History of Ideas, 1970, 31(2): 297-304.

[7] Public Record Office, London WO 32/5183, "An account of German gas cloud attacks on the British front in France"
[8] Szinicz L: History of chemical and biological Warfare agents. Toxicology, 2005, 214:175. DOI: $10.1016 /$ j.tox.2005.06.011

[9] R. Harris, R.: A higher form of Killing. Random House, 2002, 6 .

[10] https://media.nti.org/documents/1925_geneva_protocol_text.pdf

[11] Harris, R.: A Higher form of Killing. Random House, 2002, 7.

[12] http://www.johnstonsarchive.net/terrorism/ chembioattacks.html

[13] Bongar, B.: Psychology of Terrorism. Oxford University Press, 2007, 153-164

[14] https://unoda-web.s3-accelerate.amazonaws.com/wp-content/uploads/assets/ WMD/Bio/pdf/Status_Protocol.pdf

[15] https://cen.acs.org/articles/94/i41/Nazi-origins-deadly-nerve-gases.html

[16] Schmidt, U.: Secret Science. A century of Poison Warfare ad Human Experiments, 82. Oxford University Press, 2015, 77

[17] Borkin: Crime and Punishment of IG Farben. Barnes and Noble Books, 1996, 132.

[18] Schmidt, U.: Secret Science. A Century of Poison Warfare and Human Experiments, 77.

[19] Joint Planning Staff: A második világháborúban brit katonai stratégiai tervező szervezet

[20] The National Archives, Public Record Office, Prime Minister Office Files 3/89 , Military Considerations Affecting the Initiation of Chemical and Other Special Forms of Warfare"

[21] https://www.warhistoryonline.com/worldwar-ii/polish-doctor-created-fake-typhusepidemic-saved-8000-jews-wwii.html

[22] Hersh, Chemical and Biological Warfare, Doubleday, 2000, 13-18.

[23] Harris, R.: A Higher form of Killing. Random House, 2002, 147 pp.

[24] Meselson, M: The Sverdlovsk anthrax outbreak of 1979. Science, 1994, 266: 1202-1208 DOI: 10.1126/science.7973702

[25] Shoham, D.: The Russian Biological Weapons Program: Vanished or Disappeared?; Critical 
Reviews Microbiology, 2004, 30: 231-261. DOI: $10.1080 / 10408410490468812$

[26] Goldberg, R.: The Russian Strain; Wall Street Journal, 2003. március 27. https://www. ph.ucla.edu/epi/bioter/russianstrain.html

[27] Goldberg, R.: Saddam's War. Williamson National Defense University Press, 2008, 57.

[28] https://en.wikipedia.org/wiki/Use_of_chemical_weapons_in_the_Syrian_Civil_War

[29] https://www.hrw.org/news/2018/04/04/syria-year-chemical-weapons-attacks-persist

[30] https://www.opcw.org/media-centre/news/ 2001/06/sarin-gas-attack-japan-and-related-forensic-investigation

[31] Stone, F.P.: The Worried Well Response to CBRN Events: Analysis and Solutions; Air University, 2006. https://apps.dtic.mil/dtic/ tr/fulltext/u2/a475818.pdf

[32] Schep "Ricin as a weapon of mass terror separating fact from fiction". Environ. Int., 35 (8): 1267-71.

DOI: 10.1016/j.envint.2009.08.004

[33] https://en.wikipedia.org/wiki/Poisoning_of_ Sergei_and_Yulia_Skripal

[34] https://chemm.nlm.nih.gov/nerveagents/ FGA_Medical_Management_Guidelines_508.pdf

[35] Gent, N: Chemical, biological, radiological and nuclear incidents: clinical management and health protection. Public Health England, 2018

[36] Az Észak-Atlanti Szerződés https://www.nato.int/cps/en/natohq/official_texts_17120.ht$\mathrm{m}$ ? selectedLocale $=\mathrm{hu}$

[37] NATO STANAG AMedP-7.1 Medical Management of CBRN Casualties; NATO Standardisation Office, 2018

[38] NATO STANAG AMedP-7.2 CBRN First Aid Handbook; NATO Stardardisation Office, 2018
Maj. Á. Péter MDMC

\section{Strengthening the Hungarian health system's capabilities of treating casualties of chemical and biological weapons}

The danger of using chemical or biological weapons on the battlefields did not cease after the end of the first world war, even when these weapons got banned by international agreements. No chemical or biological weapon was used in large scale attacks during the second world war but during the cold both side improved these weapons to make them more efficient, more deadly. The weapons were used in proxy wars from time to time. After the cold war has ended, the chemical weapons were in operation again - for example in Iraq, Iran and Syria used both by the state army and the rebels. Terrorist groups have tried to get their hands on chemical or biological weapons. These were also used in targeted killings in the past. Therefore the possibility of victims of chemical or biological weapons emerging in the Hungarian health system can not be fully excluded. We must prepare the our health system for this possibility.

Key-words: $C B R N$, medical management, system improvement, chemical and biological weapons

Dr. Péter Ádám o. őrgy. 1134 Budapest, Róbert Károly krt. 44. 